Akreditasi KEMENRISTEKDIKTI, Nomor: 28/E/KPT/2019
heltp: / / jurnal.stkippersada.ac.id/jurnal/index.php/Vox

\title{
KAJIAN PENINGKATAN MINAT BELAJAR BAHASA MANDARIN DENGAN MEDIA LAGU
}

\author{
Merry Andriani \\ Program Studi Bahasa Mandarin, Sekolah Tinggi Bahasa Harapan Bersama \\ Email :1079415308@qq.com
}

\section{INFO ARTIKEL \\ Riwayat Artikel: \\ Menerima : 30 Agustus 2019 \\ Revisi : : 16 Nopember 2019 \\ Diterima : 29 Nopember 2019}

\section{Kata Kunci:}

Lagu, Mandarin, Bahasa,

Pengajaran, Siswa/pelajar

\section{Keywords:}

Songs, Mandarin,

Language,Teaching, Students / Students

\section{Korespondensi:}

Merry Andriani

Program Studi Bahasa

Mandarin, Sekolah Tinggi

Bahasa Harapan Bersama,Kubu

Raya, Kalimantan Barat 78391

Email:1079415308@qq.com

\section{ABSTRAK}

Penelitian ini menggunakan pendekatan deskriptif kualitatif. Penelitian ini dilakukan untuk meningkatkan minat pelajar di kota Pontianak dalam mempelajari bahasa mandarin. Metode yang digunakan dalam penelitian ini adalah pengumpulan data, observasi, wawancara, dan praktek langsung dalam kelas. Hasil penelitian ini menunjukan bahwa belajar bahasa mandarin dengan media lagu sangat mempermudah para kalangan pelajar di Kota Pontianak. Media lagu Mandarin yang dinyanyikan dengan harapan siswa dapat melatih mulut dan lidahnya serta menjadi termotivasi dalam mengikuti proses belajar. Karena media Lagu merupakan salah satu perwujudan bentuk pernyataan atau pesan yang memiliki daya menggerakkan hati, wawasan, cita rasa dan keindahan yang dapat dikomunikasikan. Media lagu juga dapat melatih siswa dalam beberapa hal seperti kemampuan mendengar, kemampuan mencatat, kemampuan berkreativitas, serta siswa dapat menanggapi isi dan pesan lagu tersebut. Maka dari itu pemanfaatan media lagu merupakan salah satu cara yang efektif untuk meningkatkan motivasi siswa dalam proses belajar.

\section{ABSTRACT}

This research use desciptive qualitative approach. This research was conducted to increase the interest of students in the city of Pontianak in learning Mandarin. The method used in this study is data collection, observation, interviews, and direct practice in the classroom. The results of this study indicate that learning Mandarin with song media greatly facilitates students in Pontianak City. The Chinese song media is sung in the hope that students can train their mouths and tongues and become motivated in following the learning process. Because the song media is one manifestation of the form of statement or message that has the power to move the heart, insight, taste and beauty that can be communicated. Media songs can also train students in a number of ways such as listening ability, notes ability, creativity ability, and students can respond to the contents and messages of the song. So from that the use of song media is one effective way to increase student motivation in the learning process.

\section{PENDAHULUAN}

\section{Dalam menjalani kehidupan}

bermasyarakat biasanya kita menggunakan bahasa sebagai alat komunikasi. Fungsi bahasa yang terutama adalah sebagai alat untuk bekerja sama atau berkomunikasi di dalam kehidupan bermasyarakat. Untuk berkomunikasi sebenarnya dapat juga digunakan cara lain, misalnya isyarat, lambang gambar atau kode- kode tertentu lainnya. Tetapi dengan bahasa komunikasi dapat berlangsung lebih baik dan lebih sempurna. Setiap bahasa sebenarnya mempunyai ketetapan atau kesamaan dalam hal tata bunyi, tata bentuk, tata kata, tata kalimat, dan tata makna. Berdasarkan hal tersebut terbentuklah keragaman bahasa. Salah satunya adalah ragam bahasa yang digunakan secara lisan yang biasa disebut bahasa lisan. 
Lawannya, ragam bahasa yang digunakan secara tertulis, atau yang biasa disebut bahasa tulisan.

Adanya era globalisasi yang membawa pengaruh cukup signifikan bagi suatu bahasa terhadap bahasa lain menjadikan dunia pendidikan mengembangkan berbagai bahasa asing. Instansi atau lembaga pendidikan di Indonesia juga sudah banyak yang menggunakan bahasa asing sebagai bahasa pengantar. Hal ini tentunya akan membawa pengaruh terhadap tenaga pengajar yang menuntut kemampuan untuk dapat melakukan pekerjaan tersebut dengan professional. Salah satu bahasa asing yang berkembang dan menjadi prioritas pendidikan bahasa adalah bahasa mandarin.

Bahasa mandarin adalah bahasa internasional kedua yang di gunakan oleh penduduk dunia dan merupakan bahasa yang paling banyak dipelajari oleh pelajar di indonesia. Persebaraan universitas swasta diskursus bahasa mandarin hampir merata di wilayah Indonesia, salah satunya di kota pontianak. Kota Pontianak memiliki beberapa universitas dan sekolah yang menjadikan bahasa mandarin sebagai mata pelajaran bahasa asing.

Dalam mempelajari suatu pengetahuan biasanya kita mempunyai peluang untuk melakukan kesalahan. Belajar bahasa sama seperti mempelajari bahasa pada diri sendiri. Ketidak tepatan maksud dari apa yang kita jelaskan sering terjadi dalam berkomunikasi. Banyak faktor-faktor yang menyebabkan hal tersebut. Dalam konteks kebahasaan hal tersebut disebut juga kesalahan berbahasa. Kesalahan berbahasa sering terjadi karena ketidak tahuan pengguna bahasa dalam mengatur tata bahasa yang benar. Ada juga faktor-faktor lain yang membuat pengguna bahasa membuat kesalahan berbahasa.

Kemalasan para pelajar pun juga nilainya sangat tinggi. Kemalasan mereka akibatnya berpengaruh pada nilai kognitif pelajar tersebut. Para pengajar Bahasa Mandarin pun meresahkan keadaan seperti ini. Pelajar sekarang mengalami kemalasan dalam hal menghafal aksara Bahasa Mandarin dengan goresan-goresan yang rumit dan susah dipahami. Itu lah penyebab pelajar malas belajar Bahasa Mandarin. Para orang tua mereka juga menginginkan para anak dapat memahami bahasa asing dengan sempurna. Tetapi anak mereka yang tidak suka mendalami bahasa asing karena pemahaman yang sulit dan dukungan dari kegiatan sehari-hari pula yang menyebabkan mereka menjadi pesimis.

Rumusan Masalah dari penelitian ini adalah Bagaimana cara meningkatkan pembelajaran Bahasa Mandarin di kalangan pelajar di Kota Pontianak?

\section{METODE PENELITIAN}

Metode penelitian dalam penelitian ini termasuk jenis pendekatan metode penelitian deskriptif kualitatif. Media yang digunakan adalah lagu. Analisis penelitian ini menggunakan observasi secara langsung dan wawancara terhadap pelajar di kota 
Pontianak. Instrument yang dibutuhkan adalah:

\section{Pengeras Suara}

\section{Tipe Recorder/HP}

\section{HASIL DAN PEMBAHASAN}

Meningkatkan minat belajar bahasa mandarin era globalisasi dengan segala kecanggihan teknologi yang ada harus melakukan inovasi terhadap proses pengajaran. Media yang bisa digunakan adalah dengan menggunakan media lagu.

\section{A. Media Lagu}

Adapun media yang dapat digunakan dalam proses belajar bahasa Mandarin salah satunya dengan menggunakan "media lagu". Mengajarkan bahasa asing memang tidak mudah. Namun, bila dilakukan dengan media seperti nyanyian, belajarpun terasa lebih menyenangkan. Melalui lagu-lagu Mandarin yang dinyanyikan, diharapkan siswa dapat melatih mulut dan lidahnya serta menjadi termotivasi dalam mengikuti proses belajar. Dalam Solechuddin (2009) dikatakan juga bahwa Lagu dapat menjadikan anak pintar terutamadi bidang logika matematika dan bahasa. Keindahan musik adalah kata-kata yang menyatu dengan nada, sehingga anak memiliki keinginan yang kuat untuk bergabung di dalamnya dan tanpa disadari anak turut berdendang dengan kata-katanya sendiri misalnya dengan menyanyikan ba..ba..ba..ba..ba,mengetuk-ngetukkan atau menjentik-jentikan jari-jari tangan atau mengangguk-anggukkan kepala setiap kali mendengar irama musik dan sebagainya. Menurut (Madyawati, 2016: 73), "Bernyanyi dapat menambah perbendaharaan kata-kata karena pada waktu bernyanyi anak dapat mendengar dan menghafal kosakata sehingga anak terangsang untuk mengungkapkan dan mengatakannya". karena siswa mendengar melalui inderanya sendiri, menyuarakan beragam tinggi nada dan irama musik dengan suaranya sendiri. Dengan mengajak siswa bernyanyi bersama dapat memberikan pengalaman berharga dan menyenangkan yang dilakukan bersama-sama. Pada saat kegiatan bernyanyi berlangsung, sebaiknya guru berada di tengah anak-anak untuk turut bernyanyi bersama siswa. Guru terlebih dahulu memberikan petunjuk sebelum melakukan kegiatan bernyanyi. Menurut (Sholehudin, 2016: 73) ada beberapa manfaat bagi anak dari kegiatan bernyanyi, yaitu :

1. Memberi ketenangan somatic

2. Menumbuhkan rasa humor

3. Merangsang kemampuan berpikir

4. Mengembangkan rasa harga diri

5. Mendukung keberhasilan pelajaran yang lain

6. Mengatasi kesulitan-kesulitan tertentu yang dialami anak

Alasan mengapa musik sangat penting untuk lingkungan Quantum Learning (membiasakan belajar nyaman dan menyenangkan) seperti yang dikatakan (Djohan, 2008: 6) 


\begin{abstract}
Bermain musik, membantu pengembangan dan koordinasi kemampuan motorik. Mempelajari sebuah karya musik dengan cara memainkannya dapat mengembangkan keterampilan musik serta membangun rasa percaya diri dan disiplin diri.Selama rileksasi dan meditasi, denyut jantung dan tekanan darah menurun dan otot - otot mengendur.
\end{abstract} Biasanya akan sulit berkonsentrasi ketika benar- benar relaks, dan sulit untuk relaks ketika berkonsentrasi penuh". Dr. Georgi Lozaroz mencari cara untuk mengkombinasikan pekerjaan mental yang menekan dengan fisiologi rileks agar melahirkan pelajar yang istimewa. Setelah melalui percobaan intensif dengan para siswa, melalui penelitiannya, beliau mendapatkan musik adalah kuncinya. Rileksasi yang diiringi dengan musik membuat pikiran selalu siap dan mampu berkonsentrasi. Dalam kehidupan sehari-hari, lagu dapat memberikan dampak nyata pada manusia seperti; menimbulkan rasa persatuan dan kesatuan, kebangsaan, keagamaan, kagum, gembira, dan sebagainya. Melalui lagu dapat melatih siswa dalam beberapa hal sebagai berikut :

1. Kemampuan mendengar, yaitu guru memperkenalkan nyanyian atau lagu, kemudian melalui kaset CD lagu tersebut diputarkan untuk didengar siswa.
2. Kemampuan mencatat, yaitu guru menyuruh siswa mencatat kosakatakosakata baru yang didengarnya dalam lagu tersebut.

3. Kemampuan berkreativitas, yaitu guru menyuruh siswa menanggapi isi dan pesan lagu tersebut.

\section{Adapun langkah-langkah dalam penggunaan media lagu dikelas dalam proses belajar mengajar sebagai berikut :}

1. Guru menjelaskan aturan dalam media lagu.

2. Guru menggunakan alat Bantu TV, kaset, CD, MP3, dan juga teks lagu yang sudah dibagikan ke siswa.

3. Guru memutar CD atau MP3 sebanyak tiga kali, dua kali untuk disimak dan satu kali untuk ditirukan

4. Guru memandu siswa untuk menirukan nyanyian dalam lagu tersebut.

5. Guru menterjemahkan lagu tersebut mulai dari kosakata yang sederhana.

6. Siswa menyimak dan mencatat kosakata yang sudah di jelaskan.

7. Siswa mengerjakan evaluasi.

\section{B. Contoh Lagu}

judul lagu : 朋友 Pengyou

Vokal : 周华健Zhou huajian

这些年一个人风也过雨也走

zhexie nian yige ren feng ye guo yu ye zou

有过泪有过错还记得 坚持什么 you guolei you guocuo haijide jianchi shenme 真爱过才会懂会寂寞 会回首 
Zhen aiguo cai hui dong hui jimo hui huishou

终有梦 终有你在心中

Zhong you meng zhong you ni zai xinzhong

朋友一生一起走 那些日子 不再有

Pengyou yisheng yiqi zou naxie rizi buzai you

一句话一辈子一生情 一杯酒

Yiju hua yibeizi yishengqing yibei jiu

朋友不曾孤单过一声朋友 你会懂

Pengyou bu ceng gudan guo yisheng pengyou ni hui dong

还有伤 还有痛还要走 还有我

Haiyou shang haiyou tong haiyao zou hai you wo

\section{Keunggulan dan Kelemahan Penggunaan Media Lagu}

Adapun kelebihan dan kekurangan penggunaan media lagu dalam proses belajar mengajar bahasa mandarin,sebagai berikut :

1. Keunggulan

a. Dapat melatih kepekaan siswa dalam mendengarkan lagu mandarin

b. Proses belajar mengajar menjadi lebih efektif

c. Membangkitkan motivasi belajar siswa

d. Menambah kosakata baru bagi siswa, misalnya: kata wǒ yang berarti saya, nǐ yang berarti kamu, laǒshù yang berarti tikus, dan sebagainya.

e. Dapat mengontrol dan mengatur tempo belajar siswa f. Menciptakan suasana belajar yang menyenangkan

g. Bahan pelajaran dapat disimpan dan diulang sesuai dengan kebutuhan

h. Mempermudah guru dalam menyampaikan materi

2. Kelemahan

a. Siswa masih mengalami kesulitan menirukan pelafalan

b. Siswa masih mengalami kesulitan dalam mengingat arti lagu

c. Belum pekannya siswa dalam mendengarkan lagu

d. Terbatasnya Waktu

\section{SIMPULAN}

Berdasarkan hasil penelitian yang

dilakukan oleh peneliti, dapat diambil kesimpulan Meningkatkan minat siswa kota Pontianak dalam mempelajari bahasa mandarin bisa menggunakan media music. Musik bisa menambah kecerdasan anak dan menjaga keseimbangan otak kanan kiri. Hal ini sangat bermanfaat untuk anak dalam menangkap pelajaran dan memahaminya. Berdasarkan penelitian para ahli, kemampuan bermain musik yang dimiliki oleh seseorang, bisa meningkatkan kecerdasan sampai 7 poin. Jadi cukup mendukung prestasi pendidikan baik di sekolah sampai perguruan tinggi. Musik juga telah banyak digunakan sebagai terapi untuk mengatasi berbagai gejala depresi dan kecemasan. Terapi musik merupakan teknik yang digunakan untuk penyembuhan dengan 
menggunakan bunyi atau irama tertentu.

\section{DAFTAR PUSTAKA}

Anonim, “ Motivasi Belajar ”. http://www.google.com// Akses 7 April 2009

Anonim, "Pengajaran Lagu Mandarin ". http://www.google.com//. Akses 2 April 2009

Arif S, Sadiman, dkk. (1990). Media Pendidikan, Pengertian,

Pengembangan, dan Pemanfaatannya. Jakarta: Rajawali

Bobbi De Porter and Mike Hernacki. 2006.Quantum Learning. Kaifa. Bandung

Madyawati, L (2016). Strategi Pengembangan Bahasa pada anak. Jakarta: Kencana

Nana Sudjana dan Ahmad Rifai. (1986). Media Pengajaran. Bandung : Sinar Baru

Mengajar. Bandung :
Martina

Solechuddin. (2008). Konsep dan Aplikasi Bimbingan Konseling. Bandung:Jurusan PPB FIP UPI 